\title{
TOWARDS A SYNTACTIC ANALYSIS OF ENGLISH AND ARABIC MULTI-WORD VERBS IN SELECTED LITERARY WORKS: A CONTRASTIVE STUDY
}

\section{Prof. Dr. Qasim Obayes Al-Azzawi (Ph.D.) ${ }^{1} \quad$ Hasan Ali Hussein $^{2}$}

${ }^{1}$ Department of English, College of Education for Human Sciences, University of Babylon, Iraq

E-mail: dr.qasim_tofel@uobabylon.edu.iq

${ }^{2}$ Department of English, Mazaya University College, Iraq

E-mail: hass29000@gmail.com

HNSJ, 2022, 3(1); https://doi.org/10.53796/hnsj3144

\section{Published at 01/01/2022}

Accepted at 27/12/2021

\begin{abstract}
The current study is concerned with a linguistic contrastive analysis of one specific feature of grammar and vocabulary in both English and Arabic languages, which is a combination of lexical verbs with adverbial and/or prepositional particle(s), which is commonly known as multi-word verbs in John Steinbeck's English novel (East of Eden) (1952) and Naguib Mahfuz's Arabic novel (Palace of Desire) [Qasr alshawq] (1957).

Furthermore, the study seeks to demonstrate that there are essential similarties and differences between English and Arabic multi-word verbs. Such parallels and differences are examined in depth through a theoretical comparison of these combinations in both languages, as well as an analysis of the two novels mentioned above.

The current study is divided into five sections: It begins with an introduction that provides an explanation to the concept of multi-word verbs in both languages, followed by the objectives, research question, hypothesis, techniques, limitations of the study, and importance of the study. The second section is devoted to the theoretical foundations of multi-word verbs in English and Arabic, respectively. It explains that English multi-word verb is a combination of two or three elements (verb + adverb, verb + preposition, and verb + adverb + preposition) that works as a single unit of meaning in the sense that its meaning cannot be deduced from the sum of its individual components' meanings. The syntactic features of such combinations include characteristics such as adverbial or prepositional particles that often combine with verbs.

The third section is intended to outline the methods used in data analysis, while the fourth section is an examination of the target verbs in the English novel and Arabic novel previously mentioned. Finally, in section 5, the findings and the results are revealed.

The current data analysis employs Quirk et al. (1985) and Celce-Murcia and Larsen-Freeman (1999) as a theoretical model for the examination of English multi-word verbs in Steinbeck's English novel (East of Eden). While Wright (1996) is also used as a theoretical model for analyzing Arabic multi-word verbs in Mahfuz's Arabic novel (Palace of Desire) [qasr alshawq]. Furthermore, Cowie (1993) is used as a practical model for multi-word verbs analysis in both languages.
\end{abstract}

Key Words: Multi-words, English Multi-word Verbs, Arabic Multi-Word Verbs, transitive, intransitive, separable, inseparable, Syntactic Features. 


\section{Introduction}

English multi-word verbs (henceforth MWVs) are verb-preposition-adverb combinations that can have two meanings: idiomatic and non-idiomatic (Swan and Walter, 2001, p.138 ). However, Arabic MWVs are the outcome of the preceding combinations but without the use of an adverb, i.e. ( lexical verb plus a preposition).

English multi-word verbs are one of the most difficult idiomatic phrases or verbs to translate into other languages for learners and translators of the English language. The semantic and syntactic complexity of such troublesome words is attributed to this difficulty.

Al-Khalaili (1979, p.5) confirms what has already been said by noting that, while being grammatically easy in many aspects, the English language poses a significant challenge to Arabicspeaking learners, particularly in its colloquial usage of a verb followed by a preposition or a particle. The current contrastive investigation is motivated by this challenging area of the two languages.

The current study attempts to demonstrate the syntactic elements of multi-word verbs in both English and Arabic in order to determine the similarities and differences between the two languages in respect to this type of verb. A collection of research questions has been proposed in order to meet the study's defined aims and to investigate the established hypotheses. They are as following:

1. What are the definitions of multi-word verbs in English and Arabic? What are these verbs called in both languages?

2. What are the primary syntactic characteristics of multi-word verbs in the two languages?

3. What are the similarities and differences in multi-word verbs between English and Arabic?

4. In which of the formal languages are these verbs used?

5. Are there structures in Arabic that are similar to those found in English MWVs?

6. Unlike English grammarians, Arabic grammarians do not categorize (verb-preposition), (verbadverb), and (verb-adverb-preposition) combinations under a particular heading, as a result, the question is whether they may be considered MWVs. And do they fulfill the EMWV's syntactic criteria?

The following hypotheses are advanced in this study:

1. Because there is no 'multi-word verbs' heading in Arabic, this study hypothesizes that (Arabic two-word verbs, verb-preposition expression, and transitive verbs with a preposition) are equivalent to English multi-word verbs, and thus the researchers claim that the target Arabic verbs are multi-word verbs as well, based on previous research.

2. Furthermore, this study hypothesizes that the target verbs in the two languages differ in form but are identical in content.

3. While English, which emphasizes multi-word verbs as one of the most significant type of idiomatic phrases, Arabic does not classify them as such. 
The following procedures are being used in the current study:

1. Presenting a multiplicity of multi-word verb meanings, structures, and syntactic properties in English and Arabic.

2. Explaining the different sorts of multi-word verbs in both languages from a syntactic standpoint.

3. Comparing English and Arabic texts to emphasize the similarities and contrasts in the usage of multi-word verbs in the two languages.

4. Quirk et al. (1985) and Celce-Murcia and Larsen-Freeman (1999) are used as theoretical models for English language throughout the investigation of thirty quotations from the two novels chosen as sample in this study. Wright (1996), on the other hand, has been used as a theoretical model for Arabic multi-word verbs. Cowie (1993) is used as a practical model for analyzing English verbs as well as Arabic verbs.

The current study intends to accomplish the following objectives:

1. Investigating multi-word verbs in English and their Arabic equivalents for the goal of contrastive analysis.

2. Demonstrating the meanings of the target verbs, as well as the most valuable and often used multi-word verbs in both English and Arabic. It may also introduce foreign learners to such verbs in both languages.

3. Examining the syntactic characteristics of multi-word verbs in both English and Arabic.

4. Giving multiple examples in both languages

5. Detecting the key points of similarity and difference between the two languages when it comes to identifying multi-word verbs.

6. Attempting to examine multi-word verbs, analyzing them, comparing them with their Arabic equivalents, noting the challenges they pose when translated into Arabic, and making a number of proposals to be considered by contrastive analysts, lexicographers, English teachers, students, and researchers to consider.

In addition, the research is limited to syntactic English multi-word verbs and their Arabic equivalents, as well as their practical application in two novels: (East of Eden) by John Steinbeck (1952) and (Palace of Desire) [Qasr alshawq] by Naguib Maf (1957).

The study is also limited to the first two chapters of the two novels since these two chapters include enough data to be analyzed and the results would be generalized.

The contributions of this study to the linguistics knowledge base are threefold:

1. It is one of the academic studies carried out to investigate the most difficult phenomenon of MWVs on a linguistic contrastive analysis framework, in order to describe and highlight the correspondences and differences in the characteristics of this phenomenon between the English and Arabic languages. 
2. It provides a syntactic classification of MWVs. This category raises awareness of the issue and, ideally, serves as a platform for academics, translators, lexicographers, and educators to improve their tactics for dealing with this problem.

3. It conducts large-scale experimental study on EMWVs and AMWVs. The huge number of utterances (30 quotes) and multi-word verbs acquired offer this study with a trustworthy amount of data, allowing the researchers to clearly verify the presence of the aforementioned phenomenon in both languages.

\section{Literature Review}

\subsection{English Multi-Word Verbs}

Linguists, grammarians, lexicographers, and pedagogues in English have dealt with multi-word verbs in a variety of ways. These authors define such verbs as verbs composed of a succession of lexical units. They are also characterized as fixed phrases whose meanings are not predicted from the meanings of their components, or a multi-word verb is an expression that acts as a single unit and whose meaning cannot be obtained from the meanings of the individual pieces (Hart,1990,p. 1).

Multi-word verbs are one of the most challenging problems for English learners and non-native speakers to solve (Nasir, 2015, p.1). They appear simple at first look to a non-native speaker, yet their meanings might differ from what one would assume.

According to English linguists and grammarians, in order to be skilled and fluent in English, you must learn the capacity to use MWVs correctly. To correctly comprehend and employ multiword verbs, however, a level of expertise that is difficult for a non-native speaker of a specific language to acquire is required (Turton \& Manser, 1985,p.6). As a result, Wallace (1981, p. 5) observes that when it comes to learning English, these phrases pose a challenge to the foreign student. Idiomatic English Multi-word verbs are a sort of MWV that causes specific difficulties for learners.

Every day, new multi-word verbs enter the language, but where do they originate from? One answer is the creation of new inventions and activities, as well as new names and verbs to characterize them ( Parkinson, 2001, p. 200). However, they are not entirely new verbs; rather, they are new combinations of existing verbs and particles, or ancient phrases that have found new applications (ibid.). multi-word verbs should not be created only from existing verbs, there are several alternatives. Nouns can also be turned into verbs and combined with particles to form new multi-word verbs. These are frequently introduced into the language through casual spoken language. So we may obtain "luck out" from the word "luck," and "wimp out" from the noun "wimps" ( ibid.).

\subsubsection{Definitions of Multi-Word Verbs in English}

Following Live (1965, p. 428), MWVs are a significant category of fundamental verbs, each of which is strongly associated with an adverbial or prepositional particle in such a way that the two parts may be seen as creating a single discontinuous verb. Heaton (1965, p. preface) observes that 
When an adverbial particle joins with a verb, it creates a collocation with a new meaning. Each multiword verb must be treated as a separate entity.

Bolinger (1971, p. xxi) defines MWV as a lexical unit in the precise sense of a nonadditive compound or derivative one with a set of meaning that is not the sum of the meaning of its parts. MWV is defined as "the verb and particle, or the verb and a group of particles, are said to comprise in this situation a sort of integral functional unit" by Sroka (1972, p.14). Furthermore, McArthur and Atkins (1974, p. 5) characterize such phenomena as "combinations of basic monosyllabic verbs (put, take, receive, etc.) with members of a set of particles (on, up, out, etc.)".

According to McArthur (1975, p. 9), a multi-word verb is constructed by combining a basic verb plus one of many particles. The outcome is referred to as 'multi' since it seems to be a phrase rather than a single word. Although it appears to be a phrase, it is only a single word. Similarly, Turton and Manser (1985, p. iv) define MWV as "a verb that incorporates two or three independent components such as: run away, come in, look forward to, and so on".

Similarly, Dixon (1991, p.274) defines MWVs as a combination of a verb and a preposition that has a meaning that cannot be inferred from the separate meanings of the verb and the preposition(s), requiring it to be viewed as an independent lexical item.

Syntactically, the components of an EMWV combination are (a verb + a preposition), (a verb + an adverb), or (a verb + an adverb + a preposition) that operate as one unit of meaning (Jacobs, 1995, p. 248). Examples of such combinations are as follows: (to turn off - to turn on - to carry out to carry on - to come out - to slow down).

According to Live (1965, p. 432), some verbs never appear independently; they are always paired with specific particles, such as: (ley, set, put, step, and others).

Dixon (1991, p.274) argues that while the student may master grammar and build a sufficient vocabulary over time, without awareness of such expressions, even the finest student's speech would sound uncomfortable and conventional.

\subsubsection{The Particles in English}

McCarthy and O'Dell (2004, p. 10) describe a particle as a short word that can be a preposition or an adverb. Furthermore, a particle can be described as an uninflected word used to express syntactical connections (Pei and Gaynor, 2007, p.123).

According to Jowett (1964, p.53), the role of the particle is useful to MWV construction because the particle affects the meaning of the verb and, at times, adds another meaning to the verb; hence, these particles have the function of constructing new verbs. As a result, the meaning of the lexical verb "make" differs from the meaning of the multi-word verb "make up", just as the verb "take" differs from "take off" (ibid.).

It is worth noting that Quirk et al. (1985, p. 1151) point out that so many verbs, such as (beaver away, egg on, and eke out), appear exclusively when coupled with particles: 
She egged him on ( ibid.)

When a particle is added to a verb, it typically adds something to the meaning, such as completeness. For example, someone can say:

1. I'll finish my work and then I'll go out (Parkinson, 2001., p. vi)

Or

2. I'll finish off my work and then I'll go out (ibid.).

\subsubsection{Syntactic Features of English Multi-Word Verbs}

Syntax is a large area, and subtopics such as transitivity and word order will be covered in this section. A pure syntactic definition of a multi - word verb can be written as follows: A multi word verb is a grammatical connection of two units: a verb and a particle, with the verb coming first and the particle coming second (ibid.).

It is vital to emphasize the key kinds of verb + particle combination here. Combinations are classified into three categories (Jacobs, 1995, p. 248):

\section{Verb + adverb combination.}

2. Verb + preposition combination.

\section{Verb + adverb + preposition combination.}

A verb + adverb combination is made up of a simple verb plus an adverbial particle, as in:

We gave up ( McArthur, 1992, p. 17).

A verb + preposition combination, on the other hand, consists of a verb and a prepositional particle followed by a prepositional object, as in:

He switches on the radio (Thim, 2012, p. 21).

Finally, a simple verb, an adverbial particle, and a prepositional particle are followed by a prepositional object in a verb + adverb + preposition combination. Jacobs $(1995$, p. 250) illustrates such a combination as follows:

Cut down on "reduce"( ibid.).

The following are summaries of the three types of verb-particle combinations:

Table (1): Verb-Particle Combinations

\begin{tabular}{|l|l|l|}
\hline No. & Combination of EMWVs & Example \\
\hline 1 & verb + adverb & I will never give in \\
\hline 2 & verb + preposition & They turn on the light \\
\hline 3 & verb + adverb + preposition & He cannot get away with it. \\
\hline
\end{tabular}

\subsubsection{Types of English Multi-Word Verbs}

The multi-word verbs will be categorized into separate types in this section. The categorization will be syntactic aspect.

\subsubsection{Syntactic Classification of EMWVs}

Multi-word verbs are classified as transitive (which can be further broken into separable and inseparable) or intransitive. 


\subsubsection{Intransitive EMWVs}

Intransitive MWVs are made up of a verb and an adverbial particle. They do not, in reality, require any object. Quirk et al. (1985, p.1152) provide the following cases as illustrations:

The plane has now taken off ( ibid.).

The plane has just touched upon (ibid.).

She turned up unexpectedly (ibid.).

The prisoner finally broke down (ibid.).

It is important to note that the adverbial particles in these MWVs function as predication adjuncts and cannot normally be separated from their lexical verbs; they are employed informally (ibid.).

\subsubsection{Transitive EMWVs}

A transitive MWV is made up of a verb, a particle, and a direct object. They require a direct object to fulfill their meaning (Quirk et al., 1985, p.1153), and they (ibid.) illustrate such MWVs as follows:

We still set up a new unit (Quirk et al., 1985, p.1153).

She's bringing up two children (ibid.).

They have called off the strike (ibid.).

\subsection{Separable Transitive EMWVs}

Transitive multi-word verbs are frequently separated by their objects, which might be a noun or a pronoun. When the object is a noun, whether it is placed between the verb and the particle or at the end after the particle is optional; both sentences below are valid (McArthur, 1992, p. 773):

I took my shoes off (ibid.).

I took off my shoes (ibid.).

When a pronoun is used as an object instead of a noun, it should be put between the verb and the particle, and only the first sentence below is acceptable:

I took them off (ibid.).

* I took off them (ibid.).

\subsection{Non-Separable Transitive EMWVs}

Components of non-separable multi-word verbs stay together; they cannot be divided by the object, as in the following example:

He ran into a tree (ibid.).

* He ran a tree into (ibid.).

Transitive verb-particle constructions, on the other hand, must be separated from prepositional verb constructions, which involve a verb and a specific prepositional phrase controlled by the verb (Quirk et al., 1985, p.1155):

They looked [at the picture] (ibid.).

She has relied [on him] for years(ibid.). 
Table (2): Separable And Non-Separable Transitive Multi-Word Verbs

\begin{tabular}{|l|l|l|}
\hline No. & Separable Multi-Word Verbs & Inseparable Multi-Word Verbs \\
\hline 1 & Bring about & Come by \\
\hline 2 & Add up & Care for \\
\hline 3 & burn up & get in \\
\hline 4 & Calm down & Pass on \\
\hline 5 & Carry over & See about \\
\hline
\end{tabular}

\subsection{Arabic Multi-Word Verbs}

The first section of the discussion presents definitions, characteristics, and syntactic categories of multi-word verbs in English. Similarly, Arabic contains linguistic aspects that have certain characteristics with English multi-word verbs (Alkhuli, 1999).

In Arabic, there are many constructions in which verbs are followed by prepositions, such as:

( يتوق الى to crave ), ( يتحدث عن to talk about), ( يعلّق على to comment on), ( يفكر to think of), and so on. In both written and spoken Arabic, these constructions are common, frequent, and widely used. However, unlike English grammarians, Arabic grammarians do not categorize such constructions, so the main question is whether they can be considered MWVs. And do they meet the previously mentioned EMWV syntactic criteria?

Actually, Arabic has a similar phenomenon, but it does not make it possible that verbs to combine with adverbs to form Arabic multi-word verb (henceforth AMWV), but allows them to merge with prepositions, as in: ( مالَ إلى mala 'ila ) which means (to like, to sympathize), and ( مالَ عَن mala 'an ) which refers to( avoid, dislike).Classical Arabic linguists did not classify these combinations under a specific title, owing to the fact that they do not include prepositions when studying Arabic verbs (Aldahesh, 2017, p. 13).

Instead, Classical Arabic linguists study prepositions in conjunction with other types of particles, which are referred to as (Huruf al-ma'ani) (meaning particles) ( Dawood, 2002, p. 11). However, most modern Arabic linguists refer to these (verb-preposition) combinations as (Aldhama'im 'enclosures') ( Al-Shamsan, 1986, p. 252).

\subsubsection{Definitions of MWVs in Arabic}

Multi-word verbs are a type of verb that consists of a sequence of lexical elements in both English and Arabic. The Arabic language consists of a linguistic item that shares some characteristics with English multi-word verbs (Mubarak, 2015, p. 8).

Another significant contribution was made by Heliel (1994) in an article addressing verbparticle combinations in English and Arabic; he approaches the issue from the standpoint of transitivity. He employs the standard classification of verbs in Arabic grammar. Arabic verbs, like English verbs, can be transitive or intransitive. The former types of verbs are known as verbs that 
pass on to their objects directly, whereas the latter verbs are known as verbs that pass on to their objects via a preposition.

To answer the question posed at the beginning of this paper, Lentzner (1977), Kharama and Hajjaj (1989), Alkhuli (1999), Najiib (2001), Bataineh and Bataineh (2002), and Nasir (2015) all agree that MWVs exist in Arabic. MWVs, on the other hand, institute a significant phenomenon in the English language, whereas the Arabic language does not recognize this phenomenon as such. According to the findings of the previous studies, Arabic grammarians do not categorize the Arabic verb + preposition combination under a specific heading.

\subsubsection{The Particles in Arabic}

The subject of prepositions attracted the attentions of contemporary Arab researchers, and as a result, various studies were conducted to investigate these prepositions and their meanings from various perspectives. The particle is referred to as ( حرف Haruf) by Arab grammarians. It is used in place of prepositions, interjections, conjunctions, and, in some cases, adverbs (Haywood \& Nahmad, 1993, p. 412). The preposition is known as (Haruf Aljer), the word governed by a preposition is known as (Almajror), and the preposition and its noun are known as (Aljar Walmajror) (ibid.).

The preposition, on the other hand, plays an important role in contradicting the meanings of sentences that are based on their components and have an indefinite meaning that is not completely clear except with prepositions.

Since it is known that the verb continues to remain general in meaning until the particles are attached to determine their meanings, then the preposition, which is one manifestation of the particle, gets a great importance in indicating the meaning, and these varied indications may reach a level of contradiction largely as a result of the combination of the verb and the preposition (ibid.).

It is important to note that prepositions are used to serve a formal purpose in the interconnectedness and association of sentence parts (Binjinny,1952). Nevertheless, the verb may accept a number of prepositions that vary in their meanings from one another, which aid in differentiating the overall meaning of the verb or sentence, even if other elements of the sentence remain unchanged. In some cases, the preposition changes the meaning of the verb to a countermeaning that is performed by using another preposition (Haywood \& Nahmad, 1993, p. 413).

\subsubsection{The Syntactic Features of AMWVs}

However, while discussing the syntactic properties of AMWVs, the essential issue is the transitivity of these verbs when it is performed by the preposition rather than the verb itself. The following example exemplifies the concept:

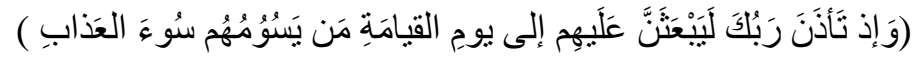

(Behold! thy Lord did declare that He would send against them, to the Day of Judgment, those who would afflict them with grievous penalty) (Ali, 1987 , p. 106)

However, the supreme preposition achieves transitivity of the verb (بَعَث على), implying preoccupation 
as Allah Almighty (Mubarak, 2015, p.9). According to Al Ghalaiyini (1994, p.39), both the Kuffians and the Bassrians linguistic schools agree that the meaning of a verb made transitive by a preposition is strongly reliant on the meaning of the preposition.

\subsubsection{Types of Arabic Multi-word Verbs}

AMWVs, like EMWVs, may be categorized based on syntactic properties.

\subsubsection{The Syntactic Classification of AMWVs}

Traditional verb categorization in Arabic grammar divides verbs into two types: transitive and intransitive verbs. The first two sorts of verbs pass on to their objects on their own. The later verbs, on the other hand, are generally known as verbs that pass on to their objects through a preposition. By using a preposition, Arabic multi-word verbs are classed as a subclass of transitive verbs.

\subsubsection{Transitive Verbs by Means of Prepositions}

This type of verbs is equivalent to EPVs. They are transitive verbs that reach their objects by a preposition with a noun that is in the genitive case which indicates that these verbs pass on their objects through a preposition (Heliel, 1994, p. 144), for instance :

( He came back home / to his country )(ibid.).

( رجع الى صوابه ( He returned to his sense) (ibid.)

Or there is:

(He broke his promise ) (ibid.).

However, the verb also could be transitive by the particle " لـ" as in Almighty saying:

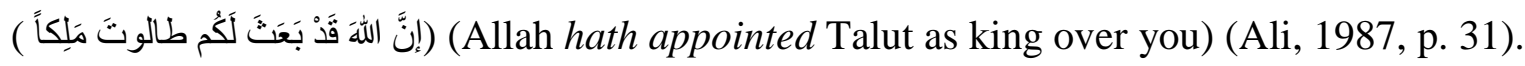

The transitivity also can be achieved by particle (فئ fii) as in the following holy verse:

(أهُ الذي بَعَثَ في الأُميينَ رَسولاً منهه ...) (It is he who has sent amongst the unlettered a messenger from among themselves...) (Ali, 1987, p. 31).

The meanings of the verb ( بَعَ) ) are attributed to the multiple use of different prepositions attached to it. Therefore all AMWVs are transitive, there is no intransitive multi-word verbs in Arabic (Alghalaiyni, 1994, p. 338).

Distinct prepositions can occasionally be attached to the same verb, resulting in different meanings ( Wright, 1996, vol.(2), p. 45); e.g.

دعاهُ ( He called him )(ibid.).

دعالهُ (He prayed that he might receive something as a blessing) (ibid.).

دعا عليه ( He cursed him)(ibid.).

\section{Methodology}

This section outlines the key elements of methodology used in the contrastive syntactic analysis of multi-word verbs in English and Arabic. Each point is treated as a distinct item in the 
analysis, in the hopes that readers will grasp such a language phenomenon and that it will be well explored.

\subsection{Research Design}

In this work, the entire analysis employs a sequential sampling technique based on nonprobability sampling methodology. As a result, the researchers correctly choose samples from the first two chapters of the two novels for analysis, ensuring that the majority of the textual quantity of each novel is covered.

The current study's scope is confined to the syntactic properties of multi-word verbs and a syntactic classification. The dictionaries selected for the present study include the following: Spears (2005) wrote "NTC's dictionary of phrasal verbs and other idiomatic verbal expressions" for English data, while Al-Ahmadi (1979) 'Mu'jam Alaf'al Almut'adia biharf' and Baalbaki (1995) 'Al-Mored: A Modern Arabic English Dictionary' for Arabic data.

\subsection{Data Collected}

The current study's data comprise phrases or utterances including multi-word verb combinations from two novels: (East of Eden) by Steinbeck (1952) and (Palace of Desire) [Qar al shawq] by Mahfuz (1957). Sentences from both novels having multi-word verbs are picked and evaluated, and two chapters from each work are chosen to identify the multi-word verbs in them. However, the researchers here use the English-translated version of Arabic data translated by Hutchins et al. (1991) as a resource for readers who do not understand Arabic.

\subsection{Methods of Data Analysis}

Quirk et al. (1985) and Celce-Murcia and Larsen-Freeman (1999) are selected as theoretical models for the analysis of English multi-word verbs in Steinbeck's English novel (East of Eden) throughout the examination of distinct passages from the two novels chosen as examples in this paper. Wright (1996) is also used as a theoretical paradigm for analyzing Arabic multi-word verbs in Mahfuz's Arabic novel (Palace of Desire) [Qasr al shawq].

Following the same procedures as the models, the researchers analyze the data in a similar but somewhat different manner. The distinctions are in the numbers and the content of the messages.

\section{Data Analysis}

The analysis processes outlined before in the section devoted to methodology are put into practice in this section. As a contrastive study, this section is divided into two sections: the first addresses the phenomenon of MWVs in English data and their meanings; their syntactic aspects and syntactic classifications. The second seeks to analyze the same phenomenon in Arabic data, as well as to state the syntactic characteristics and syntactic kinds.

As a result, this section goes through some contrastive analyses that might be used as a kind of qualitative demonstration for the two novels employed as the data under investigation. Furthermore, the results of such a demonstration are discussed later on. As examples of multi-word verbs, 
utterances from the novels mentioned above were chosen.

\subsection{Analysis of English Multi-word Verbs (EMWVs) in "East of Eden" (1952)}

This practical section will emphasize the English multi-word verbs, particularly the most often used onces in the well-known novel (East of Eden) (1952). All of the meanings for these multi-word verbs are drawn from Spears' "NTC's dictionary of phrasal verbs and other idiomatic verbal expressions" ( 2005). Similarly, the English multi-word verbs in the following quotations might be transitive or intransitive, as well as separable or inseparable.

1. " The poetry and philosophy that were going on outside the Salinas Valley".

- ( go on ): to continue an activity without stopping (Parkinson, 2001, p. 129). Or to happen (Spears, 2005 , p. 261). This multi-word verb is an inseparable unitary unit of meaning composed of two components in this regard (a verb plus a preposition). However, removing the second unit of this structure, as indicated by the model, results in a wide range of interpretations for the basic verb.

2. "The children came along as regularly as the years".

- (come along): to arrive or appear somewhere; to start to exist, happen or be available (Parkinson, ibid., p. 54). Furthermore, this verb is a syntactically intransitive multi-word verb made up of a verb and an adverbial particle. In fact, as previously stated, such MWV does not require any object and, despite its orthographic presentation as two different words, works as a single-word verb and this verb functions as a typical intransitive verb.

3. "Samuel Hamilton delivered all his own children and tied the cords neatly, spanked the bottoms and cleaned up the mess".

- (clean up): to remove dirt, etc. from a place and make it clean(Parkinson, 2001, p. 50). Furthermore, this verb is syntactically one of the primary types of MWVs, which are transitive inseparable multi-word verbs composed of a verb, an adverbial particle, and a direct object; hence, it requires a direct object to fulfill its meaning.

4. "the baby could take over for himself ".

- (take over): to take control of something (Spears, 2005, p. 678). In terms of syntax, (take over) is a manifestation of a verb plus an adverb formation, and it is an intransitive multi-word verb that does not require an object and works basically as a single-word verb.

\section{5. "To look through Dr. Gunn is to know the Hamiltons' medical history".}

- (look through): to examine the parts, pages, samples, etc. of something (Spears, 2005, p. 415). This multi-word verb, here, is classified as a verb plus an adverb. It's also an intransitive multiword verb.

6. "a gripping jaw set on its course even though the angels of God argued against it".

- (Argue against): to make a case against someone or something; or to oppose the choice of someone or something in an argument(ibid., p. 18). The concerned multi-word verb is a verb and an adverb association based on the syntactic feature of this grammatical connection. This is a 
transitive inseparable multi-word verb. Furthermore, because the particle is (against), the object must follow the particle (against), implying that the item cannot move between 'arguw' and 'against' ( Gairn and Redman, 2011, p.12).

\section{7. "Bearing her children did not hold her back very much".}

- ( hold back): to prevent sb/sth from moving forward or from entering or leaving a place( Parkinson, 2001, p. 144). The particle's mobility is an interesting feature of this multi-word verb. Because a pronoun is employed as an object instead of a noun, the pronoun is put between the verb and the particle, resulting in a transitive non-separable MWV.

8. "It wasn't very long until all the land in the barren hills near King City and San Ardo was taken up".

- (take up): to adopt something new( Spears, 2005, p. 679). The aforementioned MWV is a grammatical connection of two units: a verb and an adverb, and it is an intransitive MWV.

9. "It is argued that because they believed thoroughly in a just moral God, they could put their faith there and let the smaller securities take care of themselves".

- (believe in): to trust or have faith in someone or something; to accept a fact or what someone says as truth(Spears, 2005, p. 40). From a grammatical standpoint, this combination consists of a verb and a preposition, and it is a transitive inseparable MWV.

10. "While many people came to the Salinas Valley pen-niless, there were others who, having sold out some-where else, arrived with money to start a new life".

- (sell out): to be sold until there is no more( Spears, 2005, p. 592). The construction consists of two elements: a simple verb and an adverb that serve as one unit of meaning; one component of the construction retains its lexical meaning while the other is less transparent; consequently, such a construction is referred to as semi-idiomatic. This MWV is an intransitive one in terms of syntax.

11. "There were numbers of these families and they got the good land of the valley and cleared the yellow mustard away and planted wheat".

- (clear away): to take something away (Parkinson, 2001, p. 50). Again, the formation is the consequence of two pieces coming together: a basic verb and an adverb that operate as one unit of meaning. In terms of syntax, such a combination is a separable transitive MWV.

12. " He stumped in on a crude wooden leg he himself had carved out of beechwood".

- ( carve out of): to remove something from the inside of something else by carving or cutting(Spears, 2005, p. 88). In terms of syntax, the formation is made up of a simple verb, an adverb, and a preposition. Because such a construction necessitates the presence of an object to fulfill the meaning, it is a transitive inseparable MWV.

13. "He had in his pocket and placed on the parlor table the lead bullet they had given him to bite while they cut off his frayed leg". 
- (cut off): to isolate something from some place or something (Spears, 2005, p. 138). The basic verb is joined with an adverb, and each part of the combination retains its sense; this is the nonidiomatic form of multi-word verb type in terms of semantic frame or characteristics. This MWV is a transitive inseparable MWV in terms of syntactic properties.

14." Even then he was lucky, for the rebels retreated and the field surgeons moved up immediately".

- (move up ): to go higher ( Spears, 2005, p. 444). This MWV's constituents retain their separate meanings, which comprise the meaning of the combination; hence, it is a non-idiomatic MWV; yet, it is an intransitive MWV.

15. "Cyrus Trask did have his five minutes of horror while they cut the shreds away".

- (cut away): to remove sth by cutting with a knife or a sharp tool ( Parkinson, 2001, p. 68). Because the aforementioned verb is followed by an object, it is a separable transitive verb. And because the object is a noun, the particle can freely follow that object.

Table (3): EMWVs In "East of Eden"

\begin{tabular}{|l|l|l|l|}
\hline No. & EMWVs & Syntactic Constructions & Syntactic Type \\
\hline 1 & Go on & Verb-adverb & Intransitive \\
\hline 2 & Come along & Verb-adverb & Intransitive \\
\hline 3 & clean up & Verb-adverb & Non-separable transitive \\
\hline 4 & Take over & Verb-adverb & Intransitive \\
\hline 5 & Look through & Verb-adverb & Intransitive \\
\hline 6 & Argue against & Verb-preposition & Non-separable transitive \\
\hline 7 & Hold back & Verb-adverb & Separable transitive \\
\hline 8 & Take up & Verb-adverb & Intransitive \\
\hline 9 & Believe in & Verb-preposition & Non-separable transitive \\
\hline 10 & Sell out & Verb-adverb & Intransitive \\
\hline 11 & Clear away & Verb-adverb & Separable transitive \\
\hline 12 & Carve out of & Verb-adverb-preposition & Non-separable transitive \\
\hline 13 & Cut off & Verb-preposition & Non-separable transitive \\
\hline 14 & Move up & Verb-adverb & Intransitive \\
\hline 15 & Cut away & Verb-adverb & Separable transitive \\
\hline
\end{tabular}

\subsection{Arabic Multi-Word Verbs ( AMWVs) in (Palace of Desire) (1957) [Qașr al shawq] by Mahfouz}

This section analyzes the Arabic multi-word verbs (AMWVs), i.e. (two word verbs or transitive verbs through preposition), and their meanings in Mahfuz's Arabic book (Palace of Desire) (1957) [Qar al shawq]. The researchers, on the other hand, use the English-translated version of the Arabic data translated by Hutchins et al (1991).

Furthermore, the (verb-preposition) formulations are checked in Al-Ahmedi's (1979) "Mu'jam Alaf'al Almut'adia biharf," and the translations of Arabic multi-word verbs into English are checked in Ba'albaki's "Al-Mawrid: A Modern Arabic-English Dictionary" (1995). It's worth reminding the reader that all Arabic multi-word verbs are of the (verb-preposition) variety. Furthermore, all of the 
verbs listed below are 'transitive by way of a preposition,' meaning they might be separable or inseparable.

16. "ولئن كانت قد رَحَبت به بادئ الامر على سبيل التعزي"

" although at first she had welcomed them as an expression of her grief"(Hutchins et al.1991, p. 3).

- (رَحَّبَ بـ): to welcome (Ba'albaki, ibid., p. 579). The verb (رَحَّبَ) is coupled with the preposition (بbi) and used literally. Such a verb is a transitive multi-word verb that cannot be separated syntactically.

17. "هذا كانت تقفُ في المشربية الليالي المتعاقبة تراقب الطريق من وراء الخصائص ".

" Night after night she had stood on the balcony observing the street through the wooden grille" (Hutchins et al., ibid.).

- (وقف في) (Al-Ahmedi, 1979, p. 439): to stand (Ba'albaki, 1995, p.1244). The MWV in this case is simple to be understood and does not pose any difficulties to the non-native speaker or reader, unlike the idiomatic one. In terms of syntax, such a verb is a non-separable transitive MWV.

18. "والتفيُر يدبُ اليها غيرَ متوانٍ ".

" but change had crept through her" (Hutchins et al. 1991, p. 3).

- (يُُُبُّ الىى): to creep (Ba'albaki, ibid., p. 536). These verb is a grammatical association formed by two units: a verb and a preposition; yet, this MWVs are separable transitive verbs.

19. "هذا النادل الذي لا يستكن لله لسان"

"like this waiter who never stopped talking" (Hutchins et al., 1991, p. 3).

- (استَكَن لِ (استَكَنَ)(Al-Ahmedi, 1979, p. 158): to calm down (Ba'albaki, 1995, p. 99). The verbed with the preposition (\lrcorner $l i)$ and used in an idiomatic manner. Such a verb is a transitive multi-word verb that cannot be separated syntactically.

20. "وذو الصوت المبحوح الأي يُعَبّب على كل حوادث اليوم بلا تعَبٍ او ضَجَر" .

"the person with the hoarse voice who commented on the events of the day without getting tired or annoyed" (Hutchins et al., 1991, p. 3).

- (عقّبَ على) (Al-Ahmedi, 1979, p. 243): to comment on (Ba'albaki, 1995, p. 769). This verb is a grammatical association formed by two units: a verb and a preposition, and it is a separable transitive verb.

21. "وذو الصوت العصبي الأي يتصيد في الكومى

"the man with the nervous voice trying his luck at cards with the seven of diamonds and the jack" (Hutchins et al., ibid.).

- (يتصيّّ في): to fish in (Ba'albaki, ibid., p. 117). From a syntactic standpoint, the structure is a (verbpreposition) construction that may be categorized as a separable transitive MWV.

22. " كانت ذكريات الطريق ترتسم على مخيلتها وراء عينين لا تُفارقان الرأس المتوسد لمسند الكنبة

"Memories of the street paraded before her imagination while her eyes remained fixed on the man's head" (Hutchins et al., 1991, p. 4). 
- (ارتَسم على) (Al-Ahmedi, 1979, p.126): to come out (Ba'albaki, ibid., p. 71). The current MWV is an idiomatic combination. This verb is a separable transitive verb in terms of syntax.

23. "فلما انقطع التيار تركّز انتباهها في الرجل فتبيتت في صفحتَّي وجهه حمرة شديدة

"When the flow of remembered images stopped, she concentrated her attention on her husband. She noticed that the sides of his face were bright red" (Hutchins et al., 1991, p. 4).

- (ارنكز في)(Al-Ahmedi, 1979, p. 135): to focus on(Ba'albaki, 1995, p. 310). The structure of this MWV is (verb-preposition). However, with regard to the meaning of the combination, this MWV is semiidiomatic one.

\section{4. " "ولم تكن ترناح اليها فتساعلت في اشفاق}

"She was uncomfortable about it and asked him apprehensively" (Hutchins et al., 1991, p. 4).

- (ارتاح الى)(Al-Ahmedi, ibid., p. 142): to be satisfied with(Ba'albaki, ibid., p. 70). The aforementioned MWV is an expression whose meaning is not predictable from the meanings of their parts, actually,

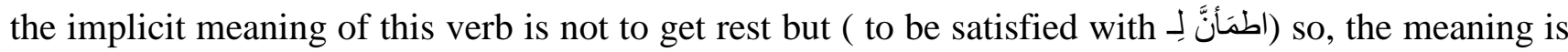
idiomatic. Syntactically speaking, this MWV results from a verb and a preposition, however, this MWV is non-separable transitive verb.

25."وسيمكُث في المفاوضة ريثما يسترد صحته"

" He will continue negotiating until he regains his health" (Hutchins et al., ibid.).

- (مكث في): to stay in (Ba'albaki, 1995, p. 1096). The MWV, here, from a syntactic viewpoint is ( verbpreposition) construction. It is non-separable transitive MWV, where the particle is placed directly after the verb.

26. "وجطوا يتحدثُن عن المفاوضة المُنتَظَرة ويُعِلقون عليها بما يحلو لهم من المُداعبات"

"They had begun to discuss the anticipated negotiations, larding their comments with whatever jests they saw fit" ( Hutchins et al., 1991, p. 4).

- (يتحدث عن)(Al-Ahmedi, 1979, p. 46): to speak about something (Ba'albaki, ibid., p. 284). The structure of this MWV is (verb-preposition) and with regard to the meaning of the combination, this MWV is an idiomatic one, that is because the elements of the construction do not keep their lexical meaning when combined together.

- (علَّقَ على) (Al-Ahmedi, ibid., p. 247): to comment on (Ba'albaki, ibid., p. 775). The present MWV is syntactically non-separable transitive one.

27. "إلتَقَت عيناهُ الحالمتان بعَينَي أمينة المُسنَطلِعتين".

"His dreamy eyes met Amina's inquisitive ones" (Hutchins et al. ibid., p. 5).

- (التقى بـ): to meet with (Ba'albaki, ibid., p. 158). It is a separable transitive MWV with respect to syntax.

28. " لم اقصر في حقه ولكني لم اصادف ترحيباً".

"I didn't neglect Yasin's rights but met with no encouragement"(Hutchins et al.,1991,p.5) 
- (فَصََرَ في )(Al-Ahmedi, 1979, p. 295): to neglect (Ba'albaki, 1995, p. 863). The MWV, here, is syntactically comes from ( verb-preposition ) construction, from a classification viewpoint, it is nonseparable transitive MWV followed by an object.

29. "والحقُ اني لا ارتضي لزينب ما ارتضيثُ لُُمهها!

" and the fact is that I have higher standards for my daughter Zaynab's husband than for her mother's"( Hutchins et al., ibid.).

- (ارتضى لـ)(Al-Ahmadi, ibid., p. 129): to choose (Ba'albaki, ibid., p. 587). syntactically, the verb ( ارتضى

\lrcorner ) is ( verb-preposition ) construction, from a classification viewpoint, it is non-separable transitive MWV followed by an object.

30. "يلوح لنا من الماضي بذكرى شاحبةٍ كهذا الضوء الخافت".

"It looms up out of the past in a pale memory, like the faint light"( Hutchins et al., ibid.).

- (لاحَ) (Al-Ahmadi., ibid., p. 336): to loom (Ba'albaki, ibid., p. 909). Semantically, the present MWV is an idiomatic one, however, syntactically speaking, it is ( verb-preposition) construction. From a classification viewpoint, it is a separable transitive MWV followed by an object.

Table (4): AMWVs in "Palace of Desire" [Qasr al shawq]

\begin{tabular}{|c|c|c|c|}
\hline No. & AMWVs & Syntactic Constructions & Syntactic Type \\
\hline 16 & رَحَّبَ بـ Welcome & Verb-preposition & Non-separable transitive \\
\hline 17 & Stand & Verb-preposition & Non-separable transitive \\
\hline 18 & Creep & Verb-preposition & Non-separable transitive \\
\hline 19 & 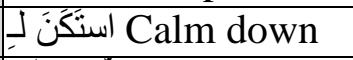 & Verb-preposition & Non-separable transitive \\
\hline 20 & عَقِبَ على Comment & Verb-preposition & Non-separable transitive \\
\hline 21 & 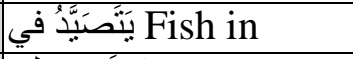 & Verb-preposition & Non-separable transitive \\
\hline 22 & Come out ارنَسَمَ على Come & Verb-preposition & Non-separable transitive \\
\hline 23 & Focus on & Verb-preposition & separable transitive \\
\hline 24 & Satisfy with & Verb-preposition & Non-separable transitive \\
\hline 25 & Stay in & Verb-preposition & Non-separable transitive \\
\hline 26 & يَتَحَدّثُ عن Speak & Verb-preposition & Separable transitive \\
\hline 27 & Comment عَلقَ على Comme & Verb-preposition & Non-separable transitive \\
\hline 28 & Meet التقى بـ. Met & Verb-preposition & Separable transitive \\
\hline 29 & فُصَّرً في Neglect & Verb-preposition & Non-separable transitive \\
\hline 30 & 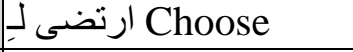 & Verb-preposition & Non-separable transitive \\
\hline 31 & لاحَ بر Loom & Verb-preposition & Separable transitive \\
\hline
\end{tabular}

\section{Conclusions}

The primary objective of this study is to look at the occurrence of multi-word verbs as a phenomenon in both English and Arabic. The other goal is to make a number of suggestions for English course designers, Arabic lexicographers, and pedagogues based on the findings of the empirical research undertaken in the study.

The study's fundamental premise is that there is a phenomena known as a multi-word verb in both languages. In this study, a collection of research questions is offered to address the theoretical portion 
of the paper as well as to examine the data acquired from a syntactic aspect.

Unlike English, which emphasizes the phenomenon of MWVs as a part of English grammar and lexicon, Arabic does not categorize analogous structures. The verb-preposition structure is the only structure in Arabic. According to a number of researchers (Lentzner, 1977; Najiib, 2001; Kharama \& Hajjaj, 1989; Alkhuli, 1999; and Bataineh \& Bataineh 2002), there are significant syntactic similarities and differences between English and Arabic. However, the following conclusions can be drawn:

1. "MWV" is defined by English grammarians as a relationship between a verb and a preposition or an adverb. While Arabic grammarians describe a MWV as a verb that impacts one or two objects using prepositions, resulting in the verb's transitivity.

2. In English, transitive verbs take on varied meanings depending on the prepositions they are linked to, and the same is true in Arabic.

3. Some multi-word verbs in English are used without an object, whereas others are used with an object. When the object is a noun phrase, it can be placed before or after the particle; when the object is a pronoun, it should be placed before the particle. In Arabic, an object should come after the multi-word verb to complete the meaning.

4. Only prepositions can be used with certain verbs to form AMWVs; adverbial particles are not permitted in Arabic combinations.

5. The preposition in AMWVs, like the particle in EMWVs, affects the meaning of the verb with which it is combined. It is critical to note that altering the particle changes the meaning of the entire structure.

6. In terms of linguistic variants, AMWVs differ from English ones in that they are less rhetorical and formal, and are used orally in everyday circumstances by everyone. AMWVs are formal, highly rhetorical documents that are typically utilized in formal situations such as political speeches, literary works, academic contexts, religious sermons, and so on. Furthermore, the majority of them are confined to written materials and are only utilized by educated individuals from a certain section of society and educational background (Aldahesh, 2008). 


\section{REFERENCES}

\section{English References}

- Aldahesh, A. Y. (2016). Pinning Down the Phenomenon of Phrasal Verbs in Arabic. International Journal of language and Linguistics. 3 (1), pp. 12-24. Sydney: The University of Sydney.

- Aldahesh, A. Y. (2017). Qur'anic Idiomatic Phrasal Verbs: Their Syntactic and Semantic Properties. International Journal of Language and Linguistics. Vol. 4,No. 3. Sydney: The University of Sydney.

- Ali, A. A. (1987) The holy Qura'n: Text, Translation, and commentary. Suadi Arabia: King Fahad Holy Qura'n Printing Complex.

- Al-Khalaili, K. ( 1979 ) . English Phrasal Verbs in Arabic . London: Hodder and Stoughton.

- Alkhuli, M. A. (1999). Comparative Linguistics: English and Arabic. Jordan: Alfalah House.

- Ary, D., Jacobs, L. and Sorensen, C. (2010). Introduction to Research In Education.(8th ed.). USA: Wadsworth. Cengage Learning.

- Bataineh, R. F., \& Bataineh, R. F. (2002). The Difficulties Jordanian Graduate Learners of English as a Second language Face When Translating English Idioms into Arabic. RASK, 16, 33-83.

- Battaglia, M. (2011)."Nonprobability Sampling". Encyclopedia of Survey Research Methods.2008. SAGE Publication.

- Celce-Murcia, M. Larsen-Freeman, D. (1999).The Grammar Book. (2 ${ }^{\text {nd }}$ ed.). USA: Heinle \& Heinle Publishers.

- Chen, J. (2007). On how to solve the problem of the avoidance of phrasal verbs in the Chinese context. International education journal, 8 (2) 348-353.

- Cowie, A. P. (1993). "Getting to grips with phrasal verbs". Vol. 9. issue (4). Cambridge University Press.

- Dixon, R. M. W. (1991). A New Approach to English Grammar on Semantic Principles. Oxford: Clarendon Press.

- Elder, S. (2009). Module 3 Sampling Methodology: School to Work Transition Survey, A Methodological Guide. Geneva: International Labour Organization.

- Etikan, I., Alkassim, R. and Abu bakar, S. (2015)."Comparison of Snowball Sampling and Sequential Sampling Techniques".

- Gravetter, F. and Forzano, L. (2012). Research Methods for Behavioral Sciences. USA: WADSWORTH.CENGAGE Learning.

- Hart, C. W. (1990). The ultimate phrasal verb book New york: Congress Library.

- Haywood, J. A. and Nahmad, H. M.( 1993). A New Arabic Grammar of the Written Language. London : Lund Humphries. 
- Heaton, J. B. (1965). Prepositions and Adverbial particles. London: Longman Group Limited.

- Heliel, M. H. (1994). Verb-Particle Combinations in English and Arabic: Problems for Arab Lexicographers and Translators. R. De Beaugrand, A. Shunnaq \& M. H. Heliel (Eds.), Language, Discourse and Translation in the West and Middle East. Amsterdam/Philadelphia: John Benjamins Publishing Company.

- Jacobs, R. A. (1995). English Syntax: A Grammar for English Language Professionals. Oxford: Oxford University Press.

- Jowett, W. (1964). On Phrasal Verbs. English Language Teaching Journal, Vol. 5, No. 6. 5270.

- Kharma, N., \& Hajjaj, A. (1989). Errors in English Among Arabic Speakers: Analysis and Remedy. London: Longman

- Kothari, C.(2004). Research Methodology: Methods \& Techniques. New Delhi: New Age International (p) Ltd.

- Lentzner, K. R. (1977). Semantic and Syntactic Aspects of Arabic Prepositions. Unpublished doctoral dissertation, Georgetown University, Washington, D. C.

- Live, A. H. (1965). "The Discontinuous Verb in English". Word (21), 428-451.

- Mahfuz, N. (1957). Qasr al shawq. (6 ${ }^{\text {th }}$ ed.) (2013). Egypt. Alqahera: Dar Alshorooq.

- McArthur, T. (1975). Using Phrasal Verbs (2 ${ }^{\text {nd }}$ ed.). London and Glasgow: Collins.

- McArthur, T. (1989). The long-neglected phrasal verbs. English Today, 5 (2), 38-44.

- McArthur, T. (Ed.). (1992). Oxford companion to the English language. Oxford/New York: Oxford University Press.

- McArthur, T., \& Atkins, B. (1974). Dictionary of English Phrasal Verbs and their Idioms. London and Glasgow: Collins.

- McCarthy, M., \& O'Dell, F. (2004). English phrasal verbs in use. New York: Cambridge University Press.

- Meyer, C. (2004). English Corpus Linguistics: An Introduction. Cambridge: Cambridge University Press. PP. xi-141.

- Mubarak, L. A. (2015). Phrasal verbs in English and Arabic: A contrastive study with reference to some scientific texts. Journal of Babylon Center for Humanities Studies, 5(1), 1-22.

- Najiib, A. M. (2001). Ausus al-tarjamah(4 ${ }^{\text {th }}$ ed.). Alqahera: maktabat ibn siinaa.

- Nasir, K. G. (2015). English and Arabic Phrasal Verbs In four selected short stories. Journal of The Thi-Qar Arts, 16 (2), 320.

- Olson, A. L. (2013). Constructions and result: English phrasal verbs as analysed in construction grammar. Unpublished Masters of Arts Thesis, Trinity Western University.

- Parkinson, D. (2001). Oxford phrasal verbs dictionary: for learners of English. Oxford: Oxford University Press. 
- Pei, M.,\& Gaynor, F.(2007). Dictionary of linguistics. Philosophical Library. New York .

- Praninskas, J. (1957). Rapid Review of English Grammar. Prentice Hall, Inc., USA.

- Quirk, R. \& Greenbaum, S. \& Leech, G. \& Svartvik, J. (1985). A Comprehensive Grammar of The English Language. London: Longman.

- Quirk, R., \& Greenbaum, S. (1973). A University Grammar of English. London: Longman.

- Showkat, N. \& Parveen, H. (2017). "Non-Probability and Probability Sampling".Pathshala

- Sinclair, J. (Ed.). (1998). Collins COBUILD Dictionary of Phrasal Verbs. London and Glasgow: Collins.

- Smeaton, B. H. (1977). The Phrasal Verb in English, by Dwight Bolinger. Cambridge: Harvard University Press, 1971. Pp. xviii 187. Canadian Journal of Linguistics/Revue canadienne de linguistique, Vol.22(1), 71-75.

- Spears, R. (2005). NTC's Dictionary of Phrasal Verbs and Other Idiomatic Verbal Phrases. Illinois: National Textbook Company (NTC) Publishing Group.

- Sroka, K. A. (1972). The Syntax of English Phrasal Verbs. The Hague and Paris: Mouton.

- Steinbeck, J. ( 1952). East of Eden. Penguin Book, New York: USA.

- Swan M. and C. Walter ( 2001). The Good Grammar Book. Oxford : O.U.P.

- Thim, S. (2012). Phrasal verbs: The English verb-particle construction and its history (Vol. 78). Walter de Gruyter.

- Turton, N., \& Manser, M. (1985). The Student's Dictionary of Phrasal Verbs. London and Basingstoke: Macmillan.

- Wallace, M. J. (1981). Dictionary of English Idioms. Glasgow and London: Collins.

- Wright, W. (1996). A grammar of the Arabic language. Vol. 2. $3^{\text {rd }}$ ed. Cambridge University Press. UK.

\section{Arabic References}

- Al-Ahmedi, Almliiani, M. (1979). Mujam ALaf'al Almut'adia Biharf (Glossary Of Transitive Verbs With A Preposition). ( $1^{\text {st }}$ ed.) Dar Al'ilm Lilmalayeen. Beirut: Lebanon.

- Alandulosy, I.(1983).Tafseer Albaher Almuheed.(AbdAlmaujood, A. A. \& M'aued A. M.). (Eds). (2001). Beirut: Dar Alkutub Al'elmia.

- Algalayini, M. (1994). Jamia'a AL-Duroos AL-Arabia. Lebanon: Beirut. Modern Institution For The Book.

- Al-Shamsan, A. I. (1986). Al-Fi'il fi al-Qu'an al-Karim Ta'adyatuhu wa Luzumuhu. Kuwait : Kuwait University.

- Baalbaki, R. (1995). Al-Mawrid: A Modern Arabic-English Dictionary. $7^{\text {th }}$ ed. Dar El-Ilm Lilmalayin. Beirut: Lebanon.

- Binjinny, A. (1952). AlKhasa's. Egypt: Dar Alkutb Alilmia, AlMaktaba Alilmia. 
- Dawood, M. M. (2002). Al-Qur'an al-Karim Wa Tafa'uul al-Ma'ani: Dirasa Dilalya li Ta'alluq Harf al-Jarr bi al-Fi'il Wa 'Atharahu fi al-Ma'na fi Al-Qur'an al-Karim. Egypt. Alqahera: Dar Gharib.

- Hutchins, W. M., Kenny, L., Kenny, O. E. (1991). Palace of Desire. The American University in Cairo Press, The Cairo Trilogy. Vol.( 2 ) Cairo: Egypt. 